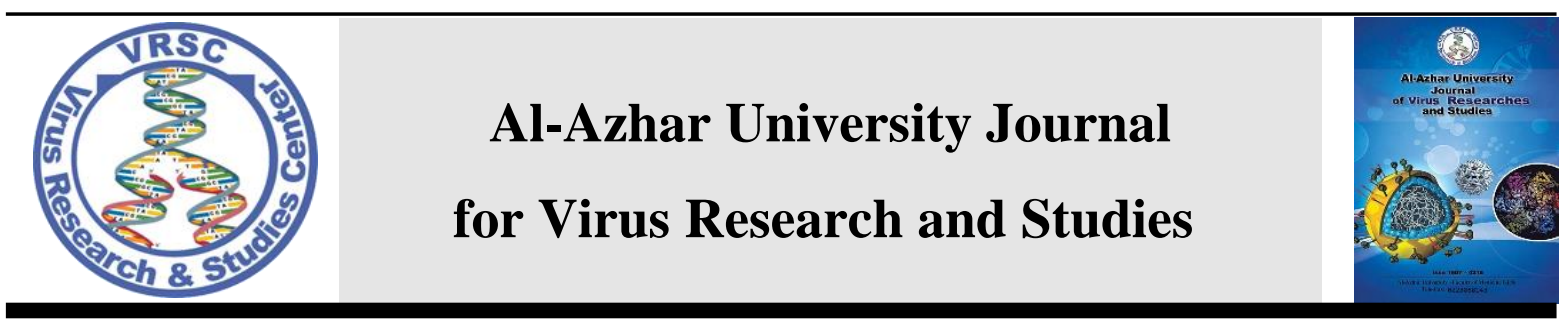

\title{
Isolation and Characterization of Soil-Borne Lytic Bacteriophages Infecting Enterobacter spp. Causing Fire Blight like Disease on Apple in Egypt
}

\author{
Rasha, A.S. El-Safty*1, Badawi, A. Othman², Ebtesam, N. Hosseny', Amal, S.M. Abo- \\ Senna $^{1}$ \\ ${ }^{1}$ Botany and Microbiology Dept., Fac. of Science, Al-Azhar Univ. (Girls Branch), Nasr \\ City, Cairo, Egypt \\ ${ }^{2}$ Agric. Microbiology Dept., Fac. of Agric, Ain Shams Univ. Shoubra El-Khima, Cairo, \\ Egypt \\ *E-mail: rasha@azhar.edu.eg
}

\begin{abstract}
Three phages showed lytic activity against Enterobacter cloacae subsp. dissolvens were isolated from the soil surrounding diseased apple trees with fire blight like disease by enrichment method. Selected phages purified by successive single plaque isolation technique. On the basis of morphotypes the isolated phages were identified as members of the Siphoviridae and Podoviride families. The phages exhibit different lytic activity against some genera of Enterobacteriaceae. Phages kept infectivity at temperatures $5-75^{\circ} \mathrm{C}$ with optimum temperature at $35^{\circ} \mathrm{C}$. About 30 to $50 \%$ of phage particles survived after treatment at $55^{\circ} \mathrm{C}$ and phages were deactivated after $85^{\circ} \mathrm{C}$. The three phages survived through $\mathrm{pH}$ range of 4 to 12 with ability to tolerant sodium chloride conc. up to $10 \mathrm{M}$. The optimum multiplicity of infection (MOI) was (0.1) for all phages. In in Vitro activity assay in liquid culture, the three phages achieved a peak reduction against their respective host compared to phage-free control. The stability of phages at high temperature and wide range of $\mathrm{pH}$, also the high lytic activity results obtained against their host make them suitable for phage biocontrol application of fire blight like disease in further study.
\end{abstract}

Keywords: Apple; Enterobacter cloacae subsp. dissolvens; Fire blight; Phages.

\section{Introduction}

Phages are virus-like particles that infect bacteria and are generally isolated from environments that are habitats for the respective host bacteria e.g., sewage, soil, water [1]. Studies of phages of plant pathogenic bacteria have a great importance in their use as a diagnostic tool [2] or in characterization of phage-bacteria interactions [3] or in biological control [4].
Bacteriophages that infect Enterobacteriaceae family are of particular interest because this bacterial family contains dangerous animal and plant pathogens. So, it can be used effectively as part of integrated disease management strategies. Phages of phytopathogenic bacteria may be isolated from soil in the vicinity of the diseased 
plant [5] and often from the diseased tissue of the plant [6].

Enterobacter cloacae is a ubiquitous Gram-negative, facultative anaerobic, rodshaped bacterium belonging to the Enterobacteriaceae family and found as a commensal in the gut flora of many humans and animals [7].

Recently, E.cloacae has increasing importance as a plant pathogen associated with internal yellowing disease of papaya [8] and internal decay of onion [9]. Moreover, E.cloacae and other species of this complex are reported as pathogenic in mulberry in China [10] and cassava in Venezuela [11].

E. cloacae subsp. dissolvens recoded to cause plant disease [12,13]. E. dissolvens infected corn and resulted in maceration rot [14], also a new disease on chili pepper seedlings caused by E. cloacae subsp. dissolvens was described [15].

Only very few phages for Enterobacter have been isolated and studied [16]. Nine phages with different lytic spectra on strains of Enterobacter sp. was isolated and studied [17], also morphologically characterizing a Podoviridae-type phage (EcP-01) against a phylloplane strain of E.cloacae isolated from tomato leaves[18]. A virulent phage F20 to Enterobacter aerogenes was isolated and characterized [19], also [20] isolated and characterized phage phiEap-2 infecting multidrug resistant Enterobacter. EspM4VN virulent phage against Enterobacter sp. M4 caused plant soft rot disease was isolated from soil and characterized [21].

The main objective of this investigation was to provide a detailed characterization and classification of the phages specific for Enterobacter cloacae subsp. dissolvens by electron microscopy and other biological tests and preparing those specific phages to be used as biocontrol agent against this plant pathogen in our further studies.

\section{Materials and Methods}

\subsection{Bacterial isolate and culture media:}

Enterobacter cloacae subsp. dissolvens [22] isolated in Virology Lab., Faculty of Agriculture, Ain Shams University, Cairo, Egypt from diseased apple trunk with symptoms of fire blight like disease. Based on Biolog metabolic profiles, carbon source utilization profiling and biochemical tests strain was identified as members of the genus Enterobacter cloacae and confirmed by sequence analysis of the partial 16S rRNA as virulent Enterobacter cloacae subsp. dissolvens LMG 2683 (R2017) isolate with accession number (NR044789.1). This bacterial isolate was Gram negative, short rodshaped $(0.4-0.6 \mathrm{um} \times 0.9-1.4 \mathrm{um})$ and facultative anaerobic endophyte bacterium cultured on nutrient agar and incubated at $30-33^{\circ} \mathrm{C}$.

\subsection{Bacteriophages isolation:}

Virulent phages specific to the target pathogen (E. cloacae subsp. dissolvens LMG 2683 (R2017) isolate) were isolated from soil samples around the diseased apple trees cultivated in Virology farm, Faculty of Agriculture, Ain Shams University, Cairo, Egypt.

Soil was added to a log-phase culture of $E$. cloacae subsp dissolvens for an enrichment culture. After shaking $\left(33^{\circ} \mathrm{C}, 150 \mathrm{rpm}, 48\right.$ hrs.), the culture solution was centrifuged (6000 rpm, $20 \mathrm{~min}, 4^{\circ} \mathrm{C}$ ). The supernatant was filtered through a pore size of $0.45 \mu \mathrm{m}$. The supernatant was tested by a spot test assay by placing $10 \mu \mathrm{l}$ on nutrient agar seeded with E. cloacae subsp. dissolvens. The positive sample was further tested by plaque assay [23].

\subsection{Bacteriophages purification:}

The phages were purified by successive single plaque isolation was carried out as 
previously described by [24] until homogenous plaques were obtained. The process was repeated 3 to 5 times in order to purify the phages and a stock of about $100 \mathrm{ml}$ of each purified phages was prepared and stored at $4^{\circ} \mathrm{C}$.

\subsection{Concentration of the isolated bacteriophages:}

Dextran sulfate-polyethylene glycol (two phase liquid system) as previously described by [25] was used to purify and concentrated the isolated phages with some modification (SM buffer $(\mathrm{NaCl} 5.8 \mathrm{~g}$, MgSO4 7H2O 2.0 g, 1M Tris $\mathrm{HCl}(\mathrm{pH} 7.4)$ $50 \mathrm{ml}$ and $2 \%$ gelatin $5 \mathrm{ml}$ per liter) was used instead of the borate buffer). Phage particles were further concentrated by highly centrifugation at $15.000 \mathrm{rpm}$ for $1 \mathrm{hr}$ at $4^{\circ} \mathrm{C}$ then the supernatants were discarded, and pellet was resuspended in 0.25 original volume sterile SM diluent and stored at $4^{\circ} \mathrm{C}$.

\subsection{Assaying of phages titer:}

Phage's concentrations were assayed before and after concentration quantitatively with the double-agar overlay method [23].

\subsection{Morphological analysis by transmission electron microscopy (TEM):}

One drop of high titer phages sample was spotted on the surface of a thin formvar carbon coated grid (200 mesh copper grid) negatively stained with $2 \%(\mathrm{w} / \mathrm{v})$ uranyl acetate as previously mentioned by [26] and were examined and photographed under Transmission Electron Microscope (JEOL-JEM.1010 TEM, Japan) at Regional Center for Mycology and Biotechnology, AL-Azhar University, Cairo, Egypt.

\subsection{Bacteriophage nomenclature:}

The nomenclature of bacteriophages was designed as previously described by [27].

\subsection{Determination of host range of the isolated phages:}

Host specify of the isolated phages was determined by the spot test as previously described by [20] against a number of different bacterial genera belong to family Enterobacteriaceae (Escherichia coli, Salmonella sp., Klebsiella and Serratia sp.) obtained from Faculty of Agriculture, MIRCEN, Ain Shams University Cairo, Egypt.

\subsection{Determination of optimal multiplicity of infection (MOI):}

Optimal multiplicity of infection (MOI) was determined for the three isolated phages separately as previously examined by [28]. E. cloacae subsp. dissolvens initially present at $\left(163 \times 10^{7} \mathrm{CFU} / \mathrm{mL}\right.$ and $\mathrm{OD}_{600}$ of 1.845) was infected with phages at two different ratios (MOI): 0.1 and 1.0 in fresh NB $(10 \mathrm{ml})$. After $18 \mathrm{hrs}$. of incubation on a rotary shaker at $150 \mathrm{rpm}$ at $30^{\circ} \mathrm{C}$, cultures were centrifuged $(6000$ rpm, $15 \mathrm{~min}$ ), chloroform treated $(10 \%$ $\mathrm{v} / \mathrm{v})$ and assayed to determine phage titer. MOI resulting in highest phage titer (the highest plaque forming units/ $\mathrm{ml}$ ) within 18 hrs. incubation was considered as an optimal MOI and used in subsequent phage propagation.

\subsection{In vitro activity of $E$. cloacae subsp. dissolvens phages in liquid culture:}

The lytic activities of the isolated phages against their host in liquid culture were determined as previously designated by [29]. 


\subsection{Characterization of phages:}

2.11.1 Effect of storage solutions on phage viability:

Phages obtained after large scale production and purification were stored in different solutions (SM buffer, nutrient broth (NB). at $4^{\circ} \mathrm{C}$ and deionized distilled water (DDW) containing 50\% glycerol at$20^{\circ} \mathrm{C}$ ). The viability of the isolated phages in this solution was assayed using over agar layer method after 6 months of storage.

\subsubsection{Determination of phages longevity in vitro:}

The isolated phages were tested for stability at room temperature $\left(25^{\circ} \mathrm{C}-30^{\circ} \mathrm{C}\right)$ and in refrigerator at $4^{\circ} \mathrm{C}$ for varying period $(2,4,6,8,10,12$ and up to 14 months) for their activity against the bacterial host (bacterial pathogen) using over agar layer method [23].

\subsubsection{Effect of temperature, $\mathrm{NaCl}$ and pH on phage viability:}

For thermal stability, phages were treated as the protocol of [30] at different temperatures at $\left(5^{\circ} \mathrm{C}, 25^{\circ} \mathrm{C}, 35^{\circ} \mathrm{C}, 45^{\circ} \mathrm{C}\right.$,

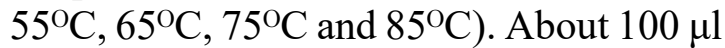
of phages $\left(10^{8}\right.$ plaque forming units (PFU) $/ \mathrm{mL}$ ) was added to $900 \mu \mathrm{l}$ nutrient broth in micro centrifuge tubes and heating at respective temperatures in water bath for $10 \mathrm{~min}$ and then cooled on ice for $30 \mathrm{sec}$ before proceeding for plaque assay, also phages tolerance to different $\mathrm{NaCl}$ concentrations $(0.05 \mathrm{M}, 0.5 \mathrm{M}, 5 \mathrm{M}$ and 10 M) was studied as done by [31]. Viability of phages in varying values of $\mathrm{pH}$ (3-12) was evaluated as previously determined by [32]. One ml portion of each phage $\left(10^{8}\right.$ $\mathrm{PFU} / \mathrm{mL}$ ) was transferred into test tubes containing $9 \mathrm{ml}$ of nutrient broth of different $\mathrm{pH}$ values (adjusted using $\mathrm{NaOH}$ or $\mathrm{HCl}$ ) and kept for $2 \mathrm{hrs}$. at $33^{\circ} \mathrm{C}$. After incubation, the surviving phages were enumerated by the double-layer agar method.

\section{Results}

\subsection{Bacteriophages isolation and}

\section{purification:}

Total of three E. cloacae subsp. dissolvens effective phages were selected on the basis of plaque morphology Fig.1 and purified by repeated plating and picking of single isolated plaques Table 1.

Table (1): Plaque morphology of the selected isolated Enterobacter cloacae subsp. dissolvens phages.

\begin{tabular}{|c|c|c|}
\hline $\begin{array}{c}\text { Phage } \\
\text { Isolates }\end{array}$ & $\begin{array}{c}\text { Plaque } \\
\text { Morphology }\end{array}$ & $\begin{array}{c}\text { Diameter } \\
(\mathrm{mm})\end{array}$ \\
\hline I & $\begin{array}{c}\text { Large sized, clear } \\
\text { plaque }\end{array}$ & 1.2 \\
\hline II & $\begin{array}{c}\text { Very small sized, } \\
\text { diffused/opaque } \\
\text { plaque }\end{array}$ & 0.5 \\
\hline III & $\begin{array}{c}\text { Small sized, clear } \\
\text { plaque }\end{array}$ & 1.7 \\
\hline
\end{tabular}

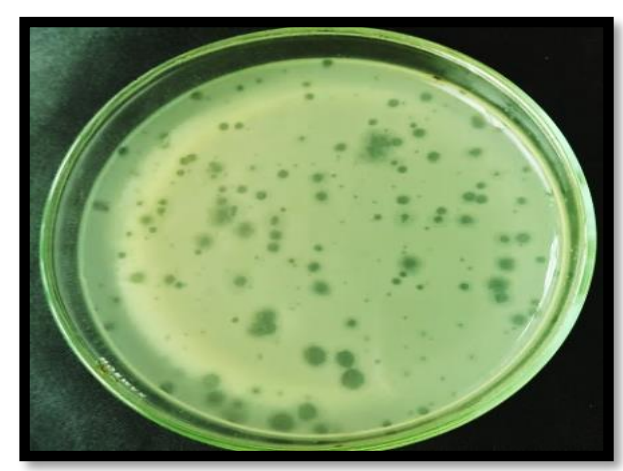

Figure (1): Variation of plaque morphology produced on doubled layer agar plates, when Enterobacter cloacae subsp. dissolvens isolate was used as the host bacterium.

\subsection{Bacteriophages Concentration:}

The three selected phages were concentrated up to $10^{9} \mathrm{PFU} / \mathrm{mL}$ using dextran sulfate-polyethylene glycol (two phase liquid system) Fig.2 and these phage concentrates prepared in large quantities as 
needed for phage characterization and for all further studies.

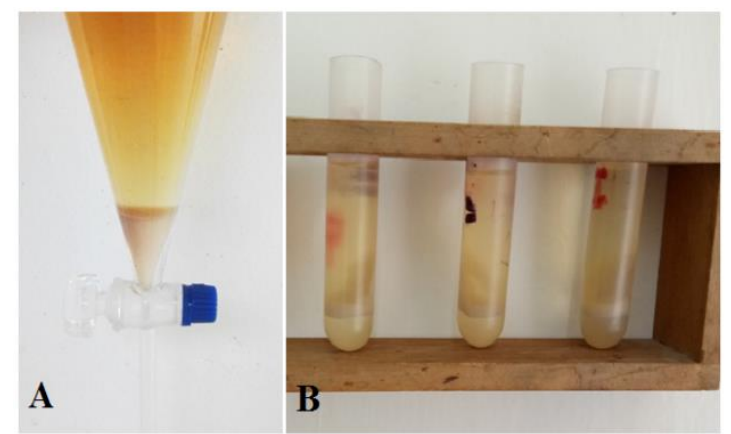

Figure (2): Purification and concentration of the isolated phages specific for Enterobacter cloacae subsp. dissolvens by dextran sulfatepolyethylene glycol, two phase liquid system. (a) Turbid bottom layer precipitate in separating funnel containing the phage particles. (b) Arrows indicate to the interface "cake" layer containing the particles of phage.

\subsection{Assaying of the purified concentrated phages:}

The spot test and plaques assay techniques were used as a type of biological assay of the phages. E. cloacae subsp. dissolvens culture was prepared at a density of $10^{7}$ $\mathrm{CFU} / \mathrm{ml}$ separately in liquid media (NB). As shown in Fig.3, the spot test (qualitatively assay) indicates that phages are present. Also, atypical plates containing single plaques resulted from plaque assay technique (quantitatively assay) were observed and the concentration of each purified E. cloacae subsp. dissolvens phages was determined separately after the concentration step as recorded in Table 2.

Table (2): Titration results of isolated phages against Enterobacter cloacae subsp. dissolvens before and after concentration step.

\begin{tabular}{|c|c|c|}
\hline \multirow{2}{*}{$\begin{array}{c}\text { Phages } \\
\text { Isolates }\end{array}$} & \multicolumn{2}{|c|}{ Number(pfu/ml) } \\
\cline { 2 - 3 } & $\begin{array}{c}\text { Before } \\
\text { concentration }\end{array}$ & $\begin{array}{c}\text { After } \\
\text { concentration }\end{array}$ \\
\hline I & $40 \times 10^{6}$ & $13.0 \times 10^{9}$ \\
\hline II & $50 \times 10^{6}$ & $19.0 \times 10^{9}$ \\
\hline III & $70 \times 10^{6}$ & $29.0 \times 10^{9}$ \\
\hline
\end{tabular}

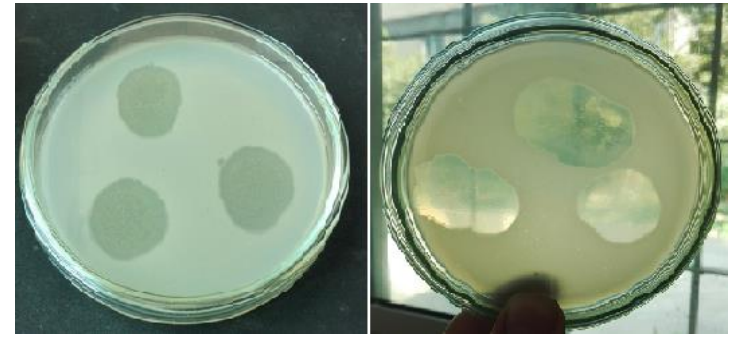

Figure (3): Purification and concentration of the isolated phages specific for Enterobacter cloacae subsp. dissolvens by dextran sulfatepolyethylene glycol, two phase liquid system. (a) Turbid bottom layer precipitate in separating funnel containing the phage particles. (b) Arrows indicate to the interface "cake" layer containing the particles of phage.

\subsection{Bacteriophage morphological and taxonomic classification:}

The obtained transmission electron microscopy data showed that the isolated Enterobacter cloacae subsp. dissolvens $\mathrm{PhI}$ had icosahedral head with diameter of $96.1 \pm 3 \mathrm{~nm}$ and long, non-contractile tail of $250 \mathrm{~nm} \pm 5 \times 15.3 \mathrm{~nm}$ width. Ph II characterized by icosahedral head of $80.4 \pm 3 \mathrm{~nm}$ diameter and long, noncontractile tail of $218 \pm 5 \times 11.8 \mathrm{~nm}$ width and PhIII characterized by icosahedral head of $57.3 \pm 3 \mathrm{~nm}$ diameter and short tail of $12 \mathrm{~nm}$ in length. Based on morphological studies, phages $\mathrm{PhI}$ and $\mathrm{Ph}$ II assigned to the family Siphoviridae while Ph III exhibited morphological traits, typical of Podoviridae family as showed in Fig.4.

\subsection{Bacteriophage's nomenclature:}

The three phages belonged to different families Siphoviridae (S) and Podoviride (P) as vB-EcS-RE.I, vB -EcS-RE.II and vB -EcP-RE.III.

\subsection{Host specificity of the phages:}

Lysosensability of some genera of family Enterobacteriaceae was tested against the three isolated phages and the results showed that, phage vB-EcS-RE.I lysed 
Salmonella sp. and Klebsiella sp. but lacked the ability to lysed E.coil and Serratia. Phage vB-EcS-RE.II lysed Salmonella sp., Serratia and Klebsiella sp. but lacked the ability to lysed E.coil while phage vB-EcP-RE.III lacked the ability to lysis any of the four tested genera .Results showed also that ,two of the isolated phages have wide host range and differed between them biologically.

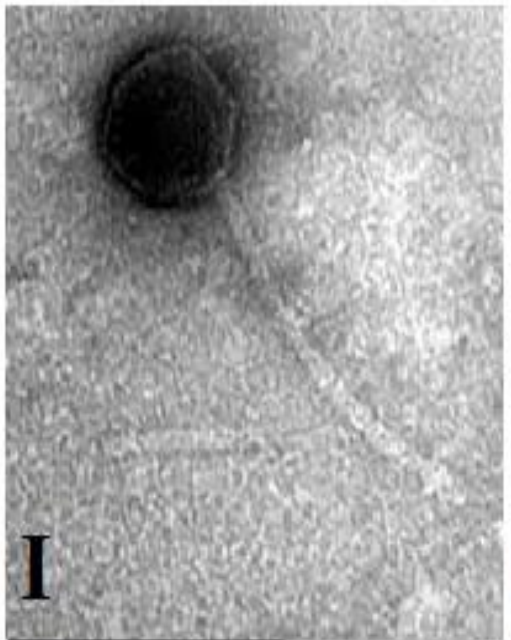

$\overline{50 \mathrm{nn}}$

TIOA Hay $=200000 \mathrm{x}$

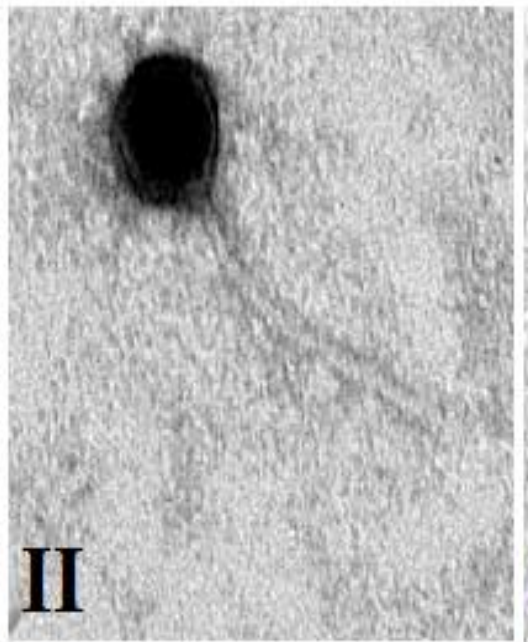

$100 \mathrm{~nm}$

TEM Mag $=100000 \mathrm{x}$

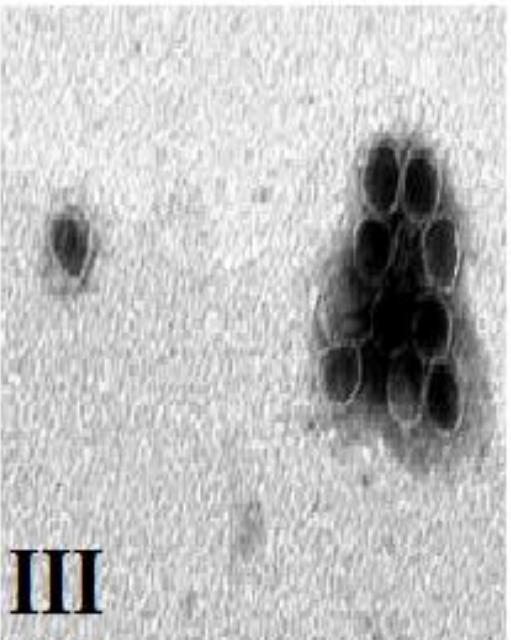

$\overline{100 \mathrm{nas}}$

TEM Mag * $100000 x$

Figure (4): Electron micrograph of purified Enterobacter cloacae subsp. dissolvens phages I, II and III that were negatively stained with $2 \%(\mathrm{w} / \mathrm{v})$ Uranyl acetate. Magnification $=100000 \mathrm{X}$.

\subsection{Determination of Optimal Multiplicity of Infection (MOI):}

The phages were added to the host bacteria with the two-input ratio (1.0 and 0.1$)$ and the obtained data showed that MOI ratio of
(0.1) showed highest phage titter as giving maximum yield of phages than ratio of (1.0) and considered as optimal MOI as recorded in Table 4 and illustrated by Fig.5.

Table (3): The effect of different MOI ratio on E.cloacae subsp. dissolvens phages titer.

\begin{tabular}{|c|c|c||c|}
\hline \multirow{2}{*}{ Phages } & \multicolumn{3}{|c|}{ Phage's titer (PFU/mI) } \\
\cline { 2 - 4 } & Start conc. & Resulted conc. at MOI of (1:1) & $\begin{array}{c}\text { Resulted conc. at MOI } \\
\text { of (1:10) }\end{array}$ \\
\hline \hline vB-EcS-RE.I & $0.246 \times 10^{9}$ & $0.306 \times 10^{9}$ & $12.2 \times 10^{9}$ \\
\hline vB - $E c S$-RE.II & $1.00 \times 10^{9}$ & $2.20 \times 10^{9}$ & $23.6 \times 10^{9}$ \\
\hline vB - $E c P$-RE.III & $3.02 \times 10^{9}$ & $3.74 \times 10^{9}$ & $37.8 \times 10^{9}$ \\
\hline
\end{tabular}




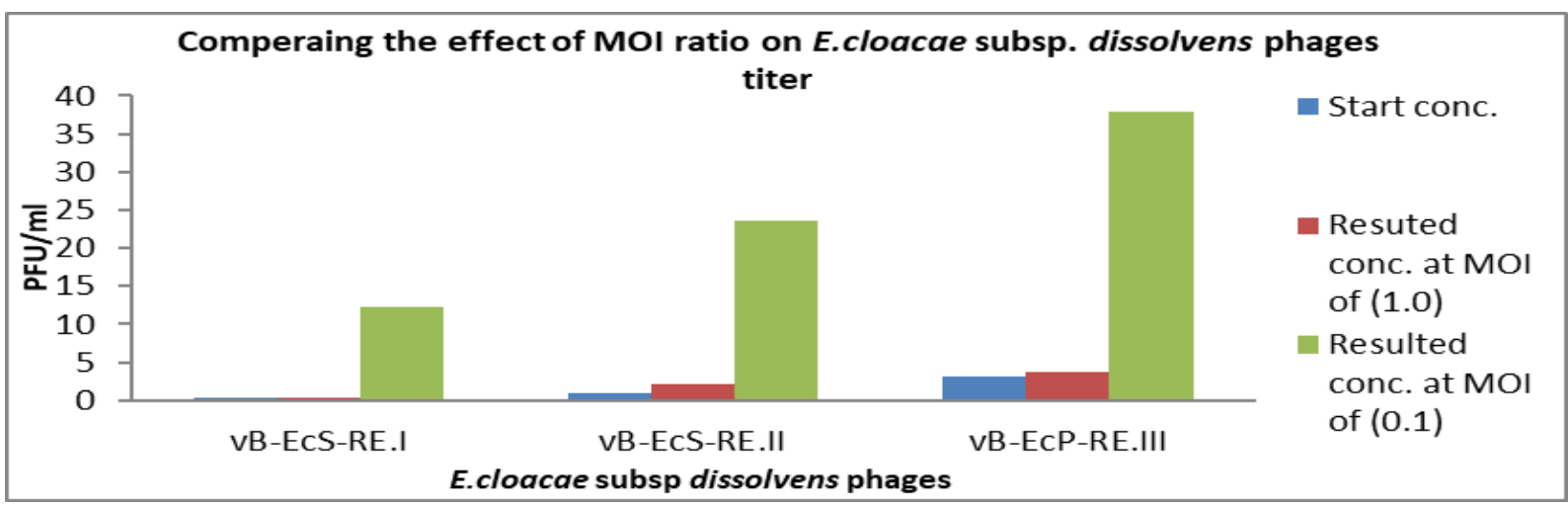

Figure (5): The effect of MOI two ratio (1.0 and 0.1) on Enterobacter cloacae subsp. dissolvens phages titer.

\subsection{Lytic activity of phages in liquid culture:}

The growth rates of the bacterial pathogen with and without the three phages are shown in Fig.6. Highest reduction rate of E.cloacae subsp. dissolvens cells count explained by decreased in optical density values and cells count were detected when phages were added at MOI of (1.0) to host cells initially present at $\left(162 \times 10^{7} \mathrm{CFU} / \mathrm{mL}\right)$ in liquid culture and compared to phagefree control. In the presence of bacteriophages viable bacteria cells reduced greatly after 2 hrs. of incubation that indicated the greater lytic activity of the isolated phages.

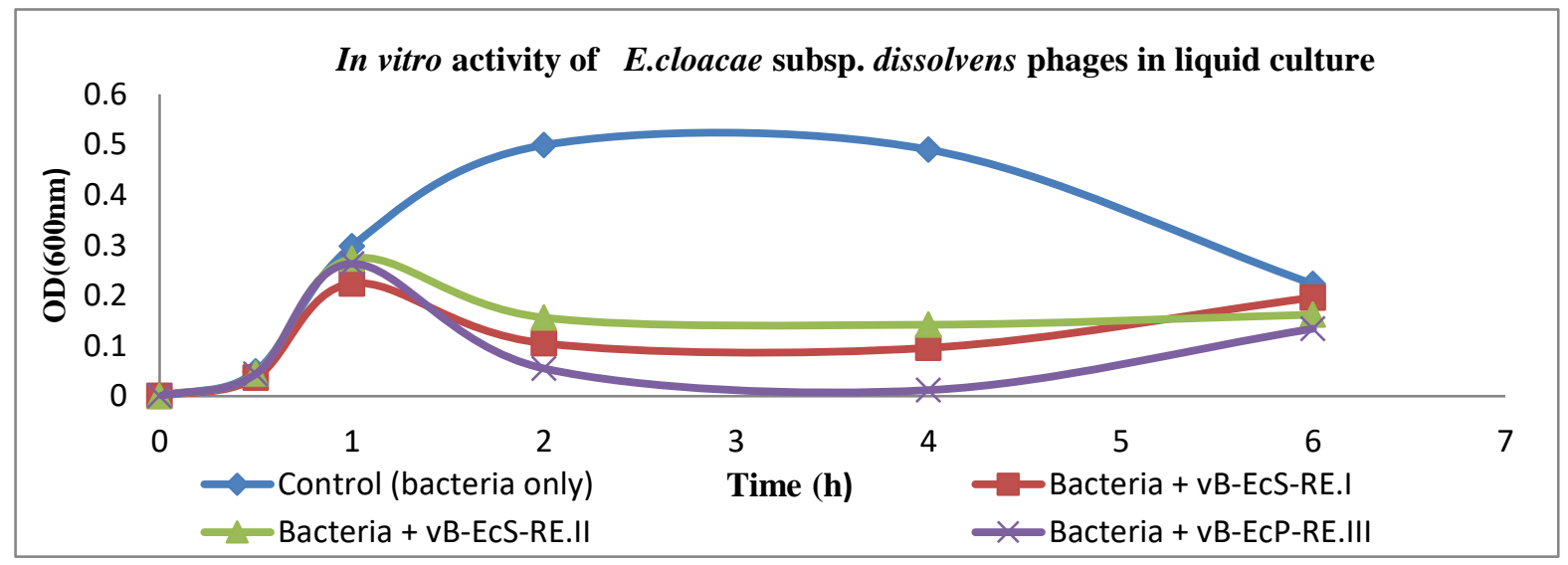

Figure (6): Lysis ability comparison of selected phages through growth curve of E.cloacae subsp..dissolvens alone (control) and in the presence of their phages at MOI (1:1).

\subsection{Characterization of phages}

\subsubsection{Effect of storage solutions on phage viability:}

All results indicated that SM buffer was the best solution for preserved of phages as there is no apparent change in titer after 6 months from storage, followed by NB while for phages in glycerol solution there is decreased in phages titer as shown in Fig.7.

\subsubsection{Determination of phages longevity in vitro:}

High titre of preserved phages in $\mathrm{NB}$ at $4^{\circ} \mathrm{C}$ and at room temperature (RT) were monitored at regular intervals over one year during the period of study. The results showed that the isolated phages sustained 
their lysis ability more than one year Fig. 8 . at refrigerator $\left(4^{\circ} \mathrm{C}\right)$ with slightly significant reduction in their titer, while at room temperature $\left(25-35^{\circ} \mathrm{C}\right)$ phages deactivated after 8 months from storage as showed in Fig.9.

\subsubsection{Phage viability in different temperature, $\mathrm{NaCl}$ concentration and pH values:}

As showed in Fig.10. E. cloacae subsp. dissolvens phages were found active between temperatures 5 to $75{ }^{\circ} \mathrm{C}$ with highest viability when exposed to $35^{\circ} \mathrm{C}$. About 50 to $30 \%$ of phage particles survived after treatment at $55^{\circ} \mathrm{C}$. Phage vB$E c P$-RE.III was more tolerant to higher temperatures than vB-EcS-RE.I and II phages also, the obtained data for the viability of the E. cloacae subsp. dissolvens phages in varying concentration of $\mathrm{NaCl}$ evident that, the optimum concentration of
$\mathrm{NaCl}$ for phages vB-EcS-RE.I and II were $0.05 \mathrm{M}$. There was significant reduction in viability at concentrations higher than $0.5 \mathrm{M}$ while phage $\mathrm{vB}-E c P$-RE.III showed their higher viability at $5 \mathrm{M} \mathrm{NaCl}$. All the E.cloacae subsp. dissolvens phages stilled survived and active even with reduced titer beyond $10 \mathrm{M} \mathrm{NaCl}$ concentrations as showed in Fig.11. E. cloacae subsp. dissolvens phages were almost stable and survived at a wide variation of $\mathrm{pH}$ between the $\mathrm{pH} 4$ to 12 with optimum activity at $\mathrm{pH}$ (7). About $75 \%$ of the phages vB-EcS-RE.I and vB-EcP-RE.III showed decreased viability at $\mathrm{pH} 4$ while no change recorded to phage vB-EcS-RE.II titer. At $\mathrm{pH} 12$ about $85 \%$ reduction for phage vB-EcPRE.III and $40 \%$ reduction for phages vB$E c S$-RE.I and II was seen only. In the acidic $\mathrm{pH}$ of 3 and alkaline $\mathrm{pH}$ of 13 , no visible plaques were observed Fig.12.

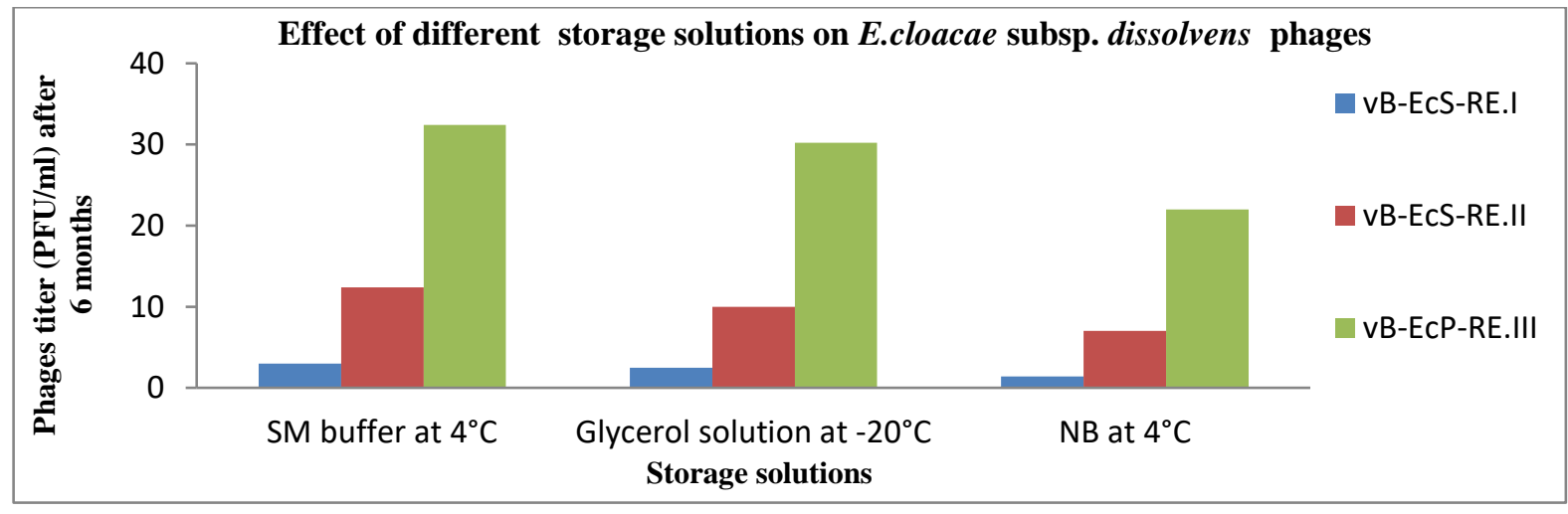

Figure (7): Effect of storage solutions on Enterobacter cloacae subsp. dissolvens phages titer.

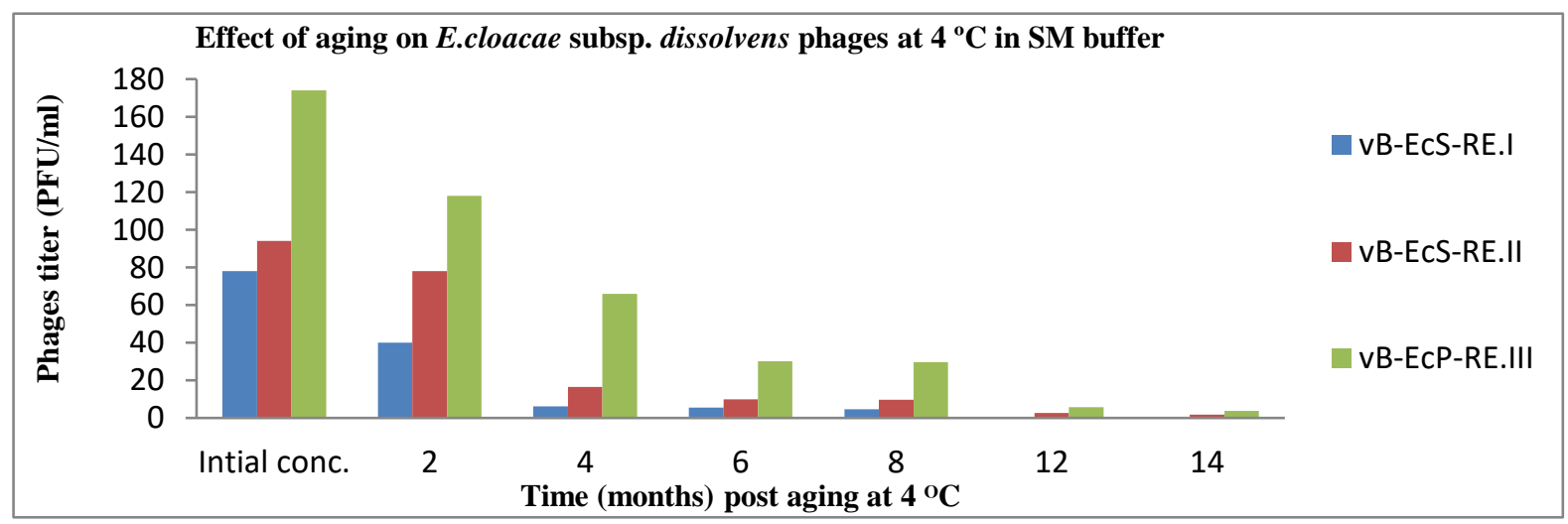

Figure (8): The longevity of Enterobacter cloacae subsp. dissolvens phages stored at $4^{\circ} \mathrm{C}$. 


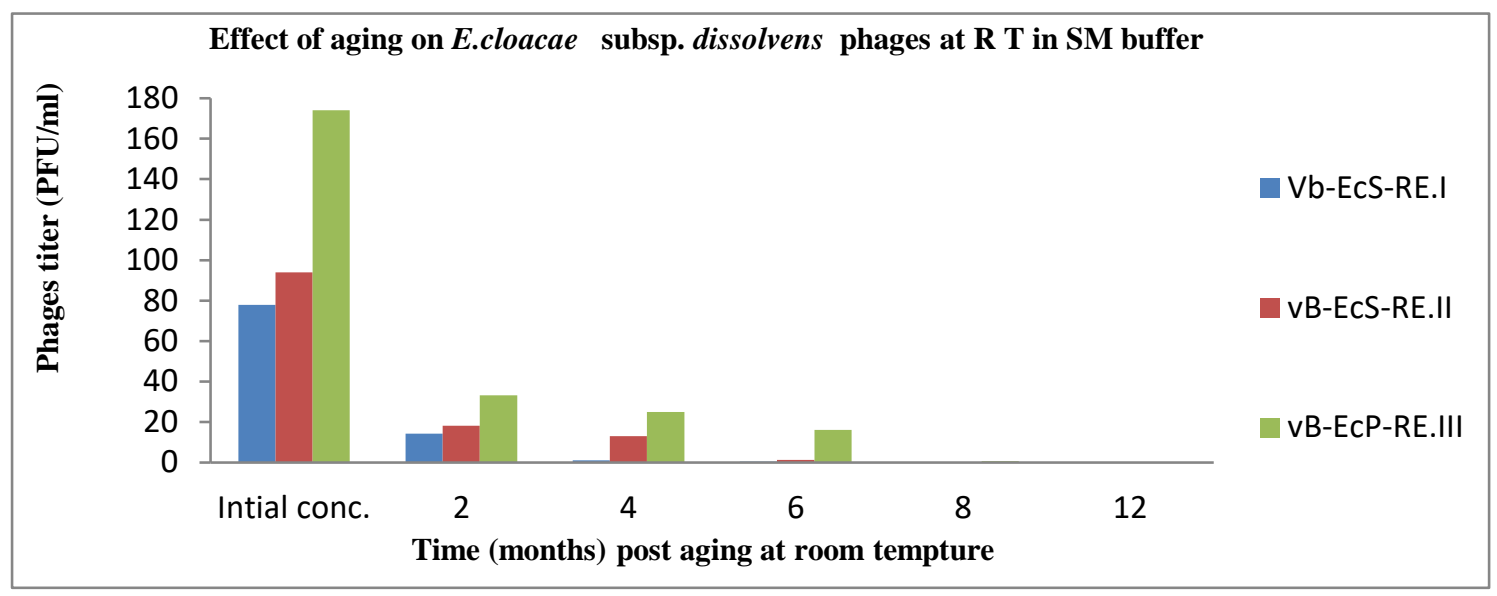

Figure (9): The longevity of Enterobacter cloacae subsp. dissolvens phages stored at room temperature.

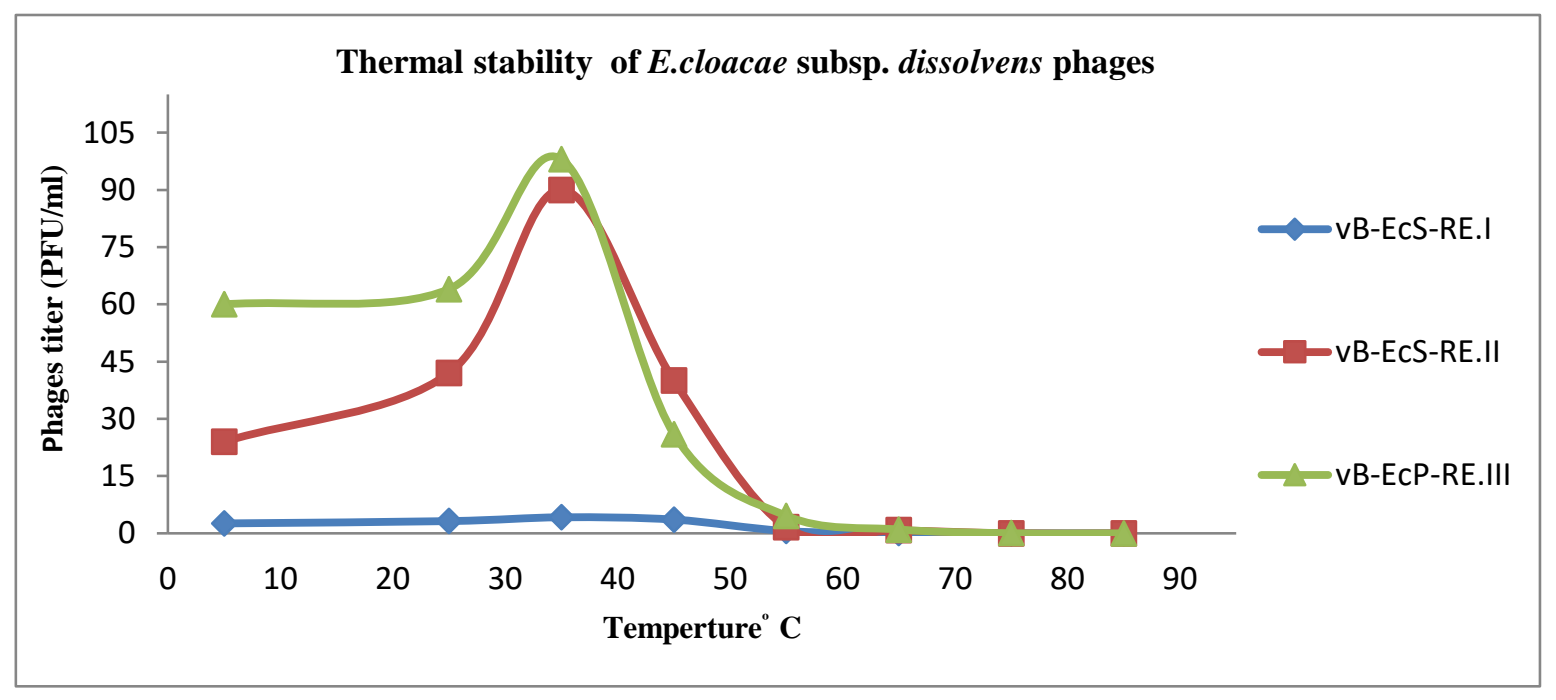

Figure (10): The thermal stability of E. cloacae subsp. dissolvens phages.

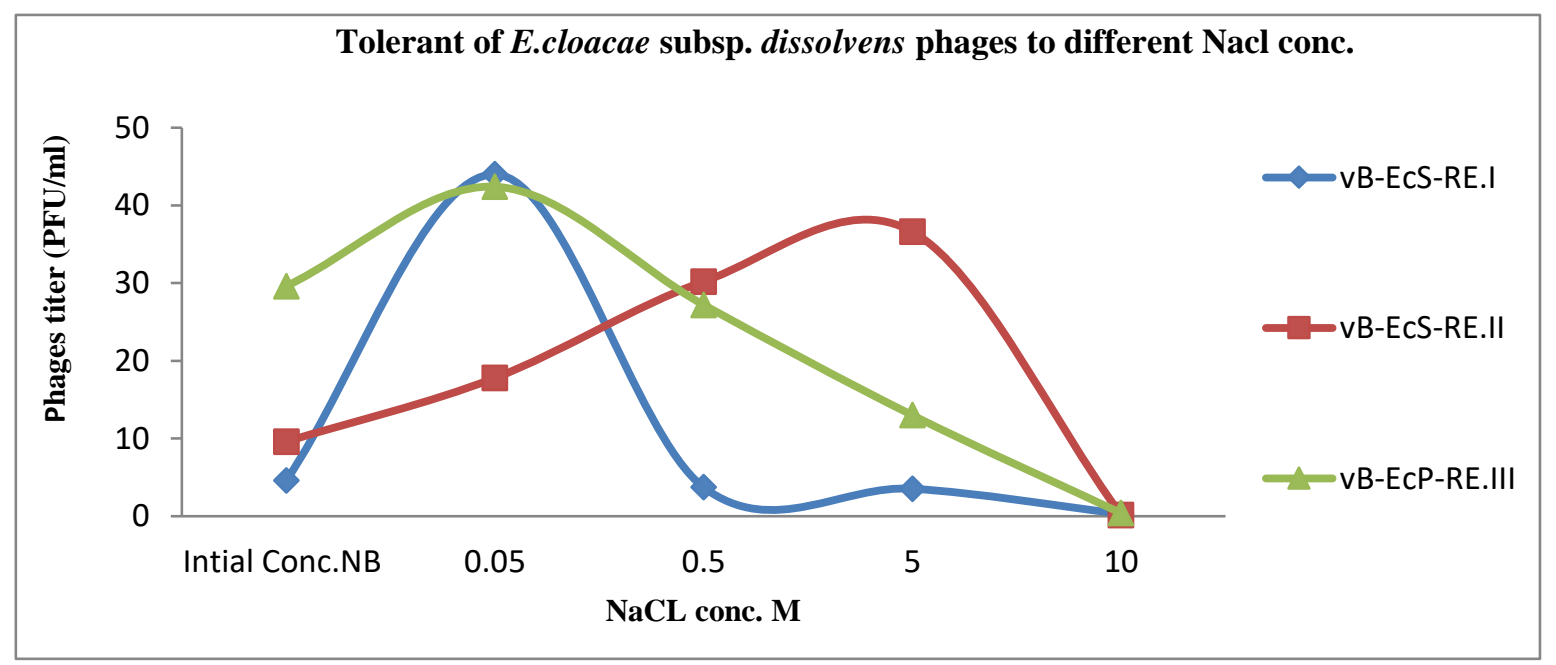

Figure (11): The $\mathrm{NaCl}$ tolerant of E. cloacae subsp. dissolvens phages. 


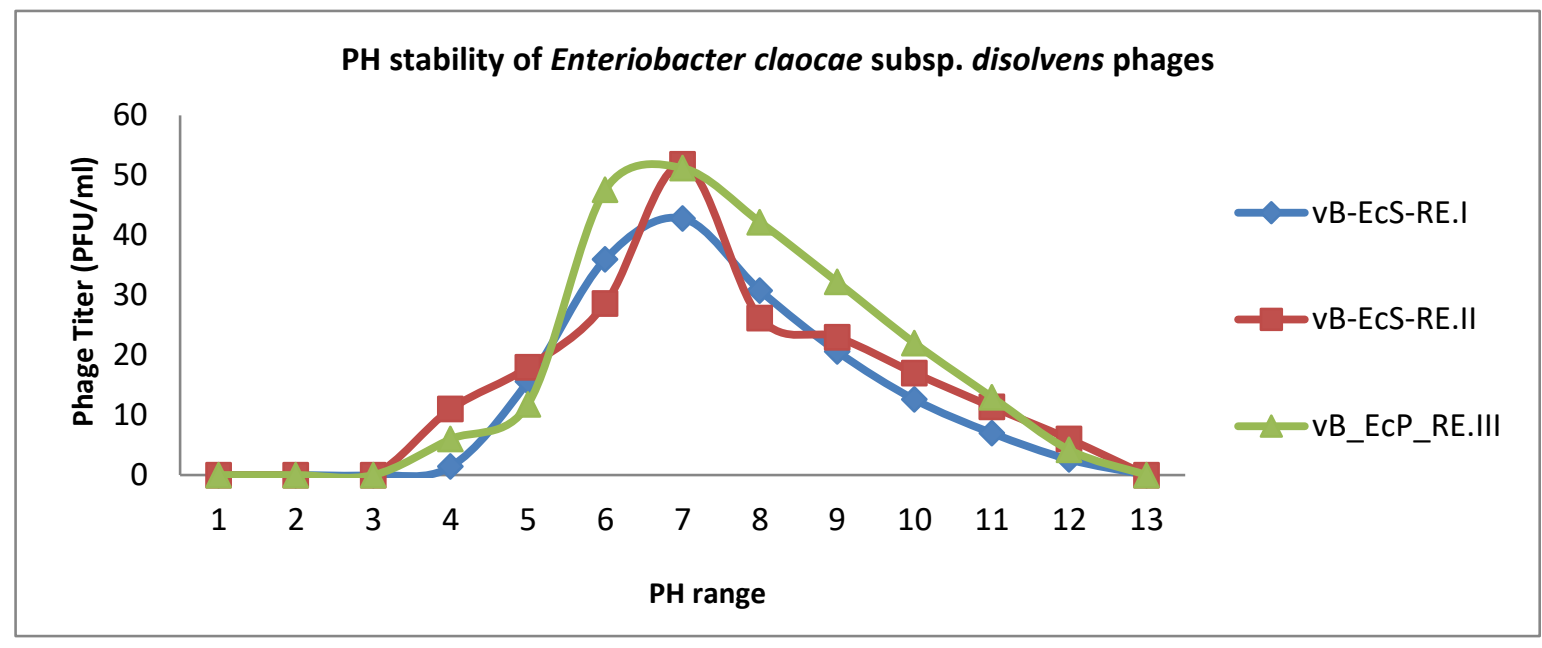

Figure (12): Effect of $\mathrm{pH}$ on the stability of E. cloacae subsp. dissolvens phages. At $\mathrm{pH} 3$ and $\mathrm{pH} 13$, the titer of the phages was zero.

\section{Discussion}

In the present study, three lytic phages, were isolated from free soil around the diseased apple trees showing the symptoms of fire blight like disease by enrichment method, similarly, to reports of [33, 43] who isolated phages specific for plant pathogen from soil.

Phages were differentiated into types according to their plaque's morphology after $24 \mathrm{hrs}$. of incubation at $30-33^{\circ} \mathrm{C}$ and purified by successive single plaque isolation until homogenous plaques were obtained $[24,30]$. Variation in the plaque morphology during the present study may correspond to the difference in phage strain [35]. Mean phage titer of lysate was $10^{9}$ PFU/ml after concentration step.In this study the best solution for storage was SM buffer as there is no apparent change in phages titer after 6 months of storage. Studying the longevity in vitro showed that the isolated phages sustained their lysis ability more than one year at refrigerator $\left(4^{\circ} \mathrm{C}\right)$ with slightly significant reduction in titer, while at room temperature $\left(25-35^{\circ} \mathrm{C}\right)$ phages deactivated after 8 months. Our results are in partial accordance with earlier reports of [19] who observed good stability of F20 specifically virulent phage to two related strains of E.aerogenes, at $25^{\circ} \mathrm{C}$ over 6 months with only a slight decrease in titre.

Based on morphological studies, phages vB-EcS-RE.I and II assigned to the family Siphoviridae while Phage vB-EcP-RE.3 exhibited morphological traits, typical of Podoviridae family. Similarly [36] reported the isolation of bacteriophages of Siphoviridae infecting E.carotovora ,also [18] succeeded in isolating and morphologically characterizing a Podoviridae -type phage (EcP-01) with an icosahedron-like isometric head (diameter, $40-50 \mathrm{~nm})$ and a short tail $(1-2 \times 0.5-0.1$ nm) against a phylloplane strain of $E$. cloacae isolated from tomato leaves. Siphoviridae phage F20 virulent to Enterobacter aerogenes was isolated and characterized by [19]. A new phage, ATCEA85, infecting Enterobacter aerogenes belongs to the family Siphoviridae with an isometric head $51 \pm 5$ $\mathrm{nm}$ in diameter and a tail $177 \pm 15 \mathrm{~nm}$ in length was reported [37].

The lytic activity of the 3 selected phages was identical with respect to their host and differed with other bacterial strains belong 
to family Enterobacteriaceae phage vB$E c P$-RE.III was restricted only to the host and phages vB-EcS-RE.I and 2 exhibit wide host range in conformity to the reports of [38] who observed that phage host range is not always genera restricted.

Phages were found active against host cells in liquid culture as phages killed its hosts almost completely after 2 hrs. while MOI of $(0.1)$ resulted in highest phage titer and conceder as the optimal multiplicity of infection. Similar MOI values for activity against specific hosts were reported for isolated phages of the family Siphoviridae [39].

The stability tests on Enterobacter cloacae subsp. dissolvens phages at different $\mathrm{pH}$, temperatures, as well as different $\mathrm{NaCl}$ conc. were performed for the potential practical application in future to control fire blight like disease as phage viability may be lost due to excessive heat and $\mathrm{pH}$ extremes as those factors cause lipid dissolving, DNA and protein denaturation, leading to phage structure damage as reported by [40].

The phages were kept viability between temperatures 5 to $75{ }^{\circ} \mathrm{C}$ with optimum temperature at $35^{\circ} \mathrm{C}$. Only about 30 to 50 $\%$ of phage particles survived after treatment at $55^{\circ} \mathrm{C}$. These findings indicated the high thermal tolerability of isolated phages. Comparatively, thermostable phages from the family Siphoviridae were reported to be stable at $60^{\circ} \mathrm{C}$ but their titers were dramatically decreased by $50 \%$ at 70 ${ }^{\circ} \mathrm{C}$ [39], also [21] reported that Enterobacter sp. M4 phage (EspM4VN) kept stable infectivity at temperatures 10 $50^{\circ} \mathrm{C}$ but deactivated at $70{ }^{\circ} \mathrm{C}$.

\section{References}

1. Vinod, M.G., Shivu, M.M., Umesha, K.R., Rajeeva, B.C., Krohne, G., Karunasagar, I. and Karunasagar, I.
No significant effect due to $\mathrm{pH}$ on viability of phage isolates was recorded and phages were stable over a broad range of $\mathrm{pH}$ from 4 to 12 . The phage infectivity was decreased towards acidic and alkaline conditions and $\mathrm{pH}$ of (6-7-8) is optimum for phages viability. Phages completely lost their viability at PH 3 and 13. Our results had agreement with [19] who found that a phage F20 virulent to Enterobacter aerogenes was stable over a broad range of $\mathrm{pH}$ from 4 to 11 and with [21] who reported that Enterobacter sp. M4 phage (EspM4VN) was stable from $\mathrm{pH} 4$ to 10 but deactivated at $\mathrm{pH} 3$ and 12 . On the contrary with [41] who reported that survival in a broad $\mathrm{pH}$ range is rarely reported for the Enterobacter phages.

All the E.cloacae subsp. dissolvens phages stilled survived and active even with reduced titer beyond $10 \mathrm{M} \mathrm{NaCl}$ concentrations and this obtained results is important for future application of phages to control plant pathogen in the soil as this studied $\mathrm{NaCl}(0.05,0.5 \mathrm{M}$ and $5 \mathrm{M})$ may occur in the soil environment [42] .

The obtained results of the reduction assay in this study which indicated completely lysed of bacterial plant pathogen Enterobacter cloacae subsp. dissolvens by the 3 isolated bacteriophages in liquid culture in addition to the phages stability indifferent temperature, $\mathrm{pH}$ and salinity, so phages can be potentially applied to kill the pathogenic bacteria in phage therapy. The proper manipulation of these highly active phages and application to plant pathogen control need further studies.

2006: Isolation of Vibrio harveyi Bacteriophage with a Potential for Biocontrol of Luminous Vibriosis in Hatchery Environments. Aquaculture, 2006. 255, 117-124. 
2. Billing, E.1963: The Value of Phage Sensitivity Tests for the Identification of Phytopathogenic Pseudomonas spp.1974. J. Appl.Bact.26:193-210.

3. Baigent, N.L., Devay, J.E, and Starr, M.P.1963: Bacteriophages of Pseudomonas syringae.N.Z.J.Sci.6:75100.

4. Kurtböke, D.I (ed) .2012: Bacteriophages. inTech, Croatia ISBN: 978- 953-51-0272-4.

5. Crosse, J.E. and Hingorani, M.K.1958: A Method for Isolating Pseudomonas mors-prunorum Phages from Soil. Nature (Lond.)181:60-61.

6. Okabe, N., and Goto, M.1963: Bacteriophages of Plant Pathogens. Annu. Rev. Phytopathol.1,397-418.

7. Fanaro, S., Chierici, R., Guerrini, P. and Vigi, V. 2003: Intestinal Micro Flora in Early Infancy: Composition and Development. Acta Paediatr. 91:48-55.

8. Nishijima, K.A., Couey, H.M. and Alvarez, A.M.1987: Internal Yellowing, a Bacterial Disease of Papaya Fruits Caused by Enterobacter cloacae. Plant Dis.71:1029-1034.

9. Schroeder, B.K., DuToit, L.J. and Schwarts, H.F.2009: First Report of Enterobacter cloacae Causing Onion Bulb Rot in the Columbia Basin of Washington State.Plant Dis.93:323.

10. Wang, G.F., Xie, G.L., Zhu, B., Huang, J.S., Liu, B., Kawicha, P., Benyon, L.and Duan, Y.P.2010: Identification and Characterization of Enterobacter Complex Causing Mulberry (Morus Alba) Wilt Disease in China. Eur.J.Plant Pathol.126:465-478.
11. Santana, M. A., Rodriguez, M., Mathehus, J., Faks, J., Bocsanczy, A., Gerstl, A., Romay, G., Montilla, J.,Fernánde, C. E., Moreno-Zambrano, N. and Marval, D. 2012: A New Bacterial Disease of Cassava n Venezuela Caused by Enterobacter cloacae. Int. J. Agric. Biol. 14:183-189.

12. Rosen, H. R. 1922: The Bacterial Pathogen of Corn Stalk Rot. Phytopathology 12:497-499.

13. Hoffmann, H. and Roggenkamp, A. 2003: Population Genetics of the Nomenspecies Enterobacter cloacae. Appl. Environ. Microbiol. 69:53065318.

14. Kado, C.I .2006: The Prokaryotes: Erwinia and Related Genera (3rd Edn.), Springer 6: 443-450.

15. García-González, T., Sáenz-Hidalgo, H.K., Silva-Rojas, H.V., MoralesNieto.,C., Vancheva, T., Koebnik,R. and Graciela Dolores Ávila-Quezada ,G.D.2018:Enterobacter cloacae, an Emerging Plant-Pathogenic Bacterium Affecting Chili Pepper Seedlings. Plant Pathol. J. 34(1): 1-10.

16. Grimont, P. A. D., Grimant, F. and Starr, M. P. 1978: Serratia Proteamaczdans (Paine and Stansfield) Comb. Nov., a Senior Subjective Synonym of Serratia Ziquefaciens (Grimes and Hennerty) Bascomb et al. Inter. J. System. Bacteriology, Oct., Vol. 28, No. 4. P. 503-510.

17. Loessner, M.J., Neugirg, E., Zink, R., and Scherer, S. 1993: Isolation, Classification and Molecular Characterization of Bacteriophages for Enterobacter species. J Gen Microbial 139: 2627- 2633. 
18. Takikawa, Y., Mori,H., Otsu,Y., Matsuda,Y., Nonomura,T., Kakutani, K., Tosa.Y, Mayama,S. and Toyoda,H. 2002: Rapid Detection of Phylloplane Bacterium Enterobacter cloacae Based on Chitinase Gene Transformation and Lytic Infection by Specific Bacteriophages Journal of Applied Microbiology , 93, 1042-1050.

19. Mishra, C.K., Choi, T. J. \& Kang, S. C.2012: Isolation and Characterization of a Bacteriophage F20 Virulent to Enterobacter Aerogenes. J Gen Virol 93, 2310-2314.

20. Li, E. , Wei,X. , Ma,Y., Yin,Z., Li,H., Lin,W., Wang,X., Li,C., Shen,L., Zhao,R., Yang,H., Jiang,A., Yang,W., Yuan,J. \& Zhao,X .2016:Isolation and Characterization of a Bacteriophage Phieap-2 Infecting Multidrug Resistant Enterobacter aerogenes Scientific

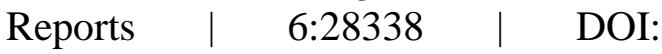
$10.1038 /$ Srep28338.

21. Thanh, N.C., Nagayoshi, Y., Fujino, Y., liyama, K., Furuya, N., Hiromasa, Y., Iwamoto, T. and Doi, K. 2020: Characterization and Genome Structure of Virulent Phage Espm4vn to Control Enterobacter sp. M4 Isolated from Plant Soft Rot. Front. Microbiol. 11:885.

Doi: 10.3389/Fmicb.2020.00885.

22. El-Safty, R.A.S., Othman, B.A., Hosseny, E.N. and Abo-Senna, A.S.M. 2020: First Report of Bacterial Fire Blight Like Disease on Apple Caused by Enterobacter spp. In Egypt. Egypt.J.Biotechnol.Vol. 61, ISSN1110 - 6093.

23. Adams, M.H.1959: Bacteriophages. New York, NY: Inter Science Publishers Inc.
24. Sambrook, J. and Russell, D.W.2001: "Picking Bacteriophage a. Plaques," In Molecular Cloning: A Laboratory Manual, 3rdedn., Vol.1 (New York, NY: Cold Spring Harbor Laboratory Press), 2.32.

25. Bachrach, U. and Friedmann, A. 1971: Practical Procedures for the Purification of Bacterial Viruses.Appl. Microbiol.,22;706-715.

26. Bradleyd, E.1967: Ultrastructure of Bacteriophages and Bacteriocins. Bacteriological Reviews 31,230-314.

27. Kropinski, A.M, Prangishvili, D. and Lavigne, R. 2009: The Creation af a Rational Scheme for the Nomenclature of Viruses of Bacteria and Archaea. Environ Microbiol 11:2775-2777.

28. Smolarska, A., Rabalski,L., Narajczyk,M. and Czajkowski,R.2018: Isolation and Phenotypic and Morphological Characterization of the First Podoviridae Lytic Bacteriophages Фa38 and Фa41 Infecting Pectobacterium Parmentieri (Former Pectobacterium Wasabiae) Eur J Plant Pathol 150:413-425.

29. Bao, H., Zhang, P., Zhang, H., Zhou, Y., Zhang, L. and Wang, R.2015: Biocontrol of Salmonella enteritidis in Foods Using Bacteriophages, Viruses, 7, 4836-4853.

30. Kerketta, P., Agarwal, R.K., Rawat, M., Jain, L., Kumar, P.P., Dhanze, H., Kumar, M.S. and Kumar, A. 2014: Isolation and Characterization of Lytic Bacteriophage (Фstiz1) Against Salmonella enterica serovars typhimurium .J . Pure and Appl. Microbiol. Vol. 8(6), P. 4719-4726 
31. Capra, M., Quiberoni, A., Reinheimer, J.2006: Phages of Lactobacillus casei/paracasei: Response to Environmental Factors and Interaction with Collection and Commercial Strains. J Appl Microbial 100:334-342.

32. Huang, C., Virk, S.M., Shi, J., Zhou, Y.,Willias, S.P., Morsy, M.K., Abdelnabby, H.E., Liu, J., Wang, X. and $\mathrm{Li}, \quad \mathrm{J}$. 2018: Isolation, Characterization and Application of Bacteriophage LPSE1 Against Salmonella enteric in Ready To Eat (RTE) Foods. Front. Microbiol. P. 9, 1046.

33. Erskine, J.M.1973: Characteristics of Erwinia amylovora Bacteriophage and Its Possible Role in the Epidemiology of Fire Blight.Can.J. Microbiol.19:837845.

34. Lagonenko, A.L, Sadovskaya, O., Valentovich, L.N, Evtushenkov, A.N.2015: Characterization of a New Vii-Like Erwinia amylovora Bacteriophage Phiea2809. FEMS Microbiol Lett 362 DOI:10.1093/Femsle/Fnv031.

35. Tiwari, R., Hirpurkar, S.D.and Shakya, S.2010: Isolation and Characterization of Lytic Phage from Natural Waste Material of Livestock. Indian Vet.J.,87:644-646.

36. Kishko, Y.G., Ruban, V.I., Tovkach, F.I., Murashchyk,I.G. and Danileychenko,V.V. 1983: Structure of Erwinia Carotovora Temperate Bacteriophage 59 and Its DNA. J Virol 46:1018.

37. Oh, H.K., Jo, J.H., wang, Y.H., and Myung, H., 2020: Complete Genome Sequence of a Novel Bacteriophage, ATCEA85, Infecting
Enterobacter aerogenes. Archives of Virology ,165:2397-2400.

38. Bielke, H., Donoghue, S., Donoghue, A. and Hargis, D.B.M. 2007: Salmonella Host Range of Bacteriophages that Infect Multiple Genera. Poult. Sci., 86: 2536-2540.

39. Lin, L., Hong, W., Ji, X., Han, J., Huang, L. \& Wei, Y. 2010: Isolation and Characterization of an Extremely Long Tail Thermus Bacteriophage from Tengchong Hot Springs in China. J Basic Microbial 50, 452-456.

40. Iriarte, F.B., Balogh, B., Momol, M.T., Smith, L.M., Wilson, M., and Jones, J.B.2007: Factors Affecting Survival of Bacteriophage on Tomato Leaf Surfaces.Appl.

Environ.Microbiol.73,1704-1711.

41. Verthe, K., Possemiers, S., Boon, N., Vaneechoutte, M. \& Verstraete, W. 2004: Stability and Activity of an Enterobacter aerogenes-Specific Bacteriophage Under Simulated Gastro-Intestinal Conditions. Appl Microbiol Biotechnol 65, 465-472.

42. Czajkowski, R., de Boer,W. J., van Veen, J. A., \& van derWolf, J. M. 2012: Characterization of Bacterial Isolates From Rotting Potato Tuber Tissue Showing Antagonism to Dickeya Sp. Biovar 3 in Vitro and in Planta. Plant Pathology, 61, 169-182. 